\title{
5. EFFICIENCY OF ARTISTIC EDUCATION: PRAXIOLOGICAL APPROACH
}

\author{
Tatiana Bularga
}

\begin{abstract}
In our statements we proceed from the reality that the artistic activity differs much from other human activities through its ontological specifics, which requires taking into account the opportunities and challenges that arise in individual potential manifestation of the child, act that expresses by transposing the theoretical prescriptions into practical actions indisputable by the presence of emotional-affective reactions, by developing projects and logistical maps of action, is not waiting for certain stimuli coming from outside, but by enhancing the artistic intentions and decisions of child - subjects of education. In efforts to design the implementation process of innovative artistic praxeology we emerged from the assumption that TDA (teacher's didactic action) and PAA (pupil artistic action) become fundamental values of the integration of theory and praxeology in perspective of an effective education, provided that they be widely used both horizontally and vertically, according to the pentagonal model consisting of principles: proactivity, artistic intro-opening, creation/creativity, of success, re-conceptualizing and instrumented in modern theoretical and methodological perspectives.
\end{abstract}

Key words: artistic activity, proactivity, artistic intro-opening, creation/creativity, success, innovative artistic praxeology, integration of theory and praxeology

\section{Introduction}

The sustainable study of practice in artistic education in the Republic of Moldova proves quite convincing that there is a considerable discrepancy between artistic theory and praxeology, which negatively influences the management of the implementation of an innovative praxeology, the training through innovation. In the field of personality formation through art, we notice that the practice does not meet the specific technological need for the processes of reception-understandingcreation of works of art. In this educational field, the approach for optimizing the theory - practice relationship obtains additional instructive-formative and artistic development values, due to the principles of creation / recreation-reception of artistic products, which stipulate that the work of art exists as such only in the process of its interpretation-visualization-hearing - a process that integrates the mental action of the author of creation, considered conventionally as a theoretical one, with the action of reception and, at the same time, being considered as a practical one.

The process of artistic reception within the instructive-formative actions is identified with the educational action itself. In this process, a considerable weight belongs to the participatory state of the pupil / student in the action of design, development and evaluation / self-evaluation (by prescribing individual behavioral maps, anticipating practical actions, varying operations, accomplishing tasks by choosing variants for the optimal solving) and the dynamics of the teacher's

\footnotetext{
${ }^{252}$ Associate Professor PhD., „Alecu Russo” State University from Bălţi, Republic of Moldavia, email:
} tatianabularga@rambler.ru 
professional competence to gradually achieve the process of design (theoretical) and action (practice), by identifying educational content and value actions, diagnosing individual resources, planning, hypothesis formation, sequential and final evaluation. The following are identified as efficiency criteria:

1. Methodological (planned and carried out considering the application of technologies and efficiency strategies);

2. Psychological (taking into account the psychic factors, the internal content of the personality);

3. Physiological (student-subject-object / object of education is a being endowed with mental / spiritual abilities, but also with physical abilities, which implies the promotion of a binomial educational policy, with an efficient connection of both forms of existence);

4. Pedagogical (use of modern principles and technologies of efficient management with the educational-formative process);

5. Aesthetics (all cognitive-formative steps to be performed based on classical and contemporary knowledge);

6. Praxeological (the didactic actions of the teacher and the artistic actions of the pupil to be instrumented and substantiated methodologically and realized with a high practical effect);

7. Axiological (education is value-centered and integrated);

8. Sociological (artistic education is a microsystem of the society of which the person is part and which, respectively, determines his formative purpose and ideal).

Based on the criteria highlighted above, we conclude that the education / preuniversity education (pre-university and university framework) in the Republic of Moldova, if we refer to the whole, attests aspects that still remain to be capitalized inefficiently. The realization of the investment program, but also the applicativepractical one, taking into account the examined factors, inevitably leads to the minimization of the distance between the theory and the practice of the targeted field. In this sense, we aim to significantly optimize the process of implementing the concept of artistic efficiency by promoting a progressive vision, which lies in cultivating in practitioners not only a receptive praxeological style, but also a formative and innovative praxeology.

\section{Discussions}

In our statements we emerge from the reality that artistic activity differs greatly from other human activities by its ontological specificity, which requires taking into account the opportunities and apparent challenges in manifesting the individual potential of the student, an act that is expressed by transposing theoretical prescriptions in practical actions indisputably by the presence of emotional-affective reactions, by experiencing projects and logistical maps of the action, not only waiting for incentives from outside, but by strengthening the intentions and artistic decisions of the student - subjects of education.

Emerging from such educational-philosophical perspectives, we realize well that, for example, that the act of musical perception of the listener is not one of strictly artistic or strictly musical imagination. So the activity of the actor of the 
reception process, related to this field, is an action with a wider radius of influence, with the name of musical-artistic action. For these reasons, the notion of artistic is not an artificial supplement to the word musical, but represents a content with an integrated, unique meaning.

Currently, in the environment of theorists and practitioners, the question is increasingly insistent: What are the requirements and criteria for the effectiveness of arts education? In a certain way. From the perspective of an efficient artistic education, the imperative of rethinking the taxonomy of educational objectives is advanced. Thus, it is logical to fundamentally investigate such a requirement towards the theory and praxeology of artistic education, which derives from the content of the theory-praxis relationship (conceptualization and realization).

Taking into account the conceptual approaches set out above, every school hour, every cycle of subjects in artistic education must emphasize the levels of learning, namely: the knowledge of phenomena (What is this?), The acquisition of knowledge and new skills (What should I do?), achievement by transfer of those acquired in new situations (How to do?), evaluation / self-evaluation of success variables (What is the effectiveness of the action?). The musical-artistic activity conceived, in general, as a specific educational field - oriented towards increasing the quality of the action of the same name, as well as the whole system of artistic education, is regulated by five praxeological principles, which underlie the strengthening of the concept of the efficiency of national artistic education and not only.

The principle of proactive personality education, which is conceived as a managerial tool for self-management and self-improvement, is achieved through: design, decision, option, initiative, independence, intra-independence. Broadly speaking, proactivity is a defining quality of man, and has a regulatory function for all mental actions (internal) and behaviors (external), which are in continuous dynamics and development. Such a quality is not a simple reaction to internal or external incentives, but an attitudinal state, manifested by assuming one's own initiatives, an integral quality, formed and realized by the person consciously.

Proactivity is the result of a system of activities directed and promoted based on the choice of operations and favorable conditions, aimed at streamlining the training process through internal change. Proactivity does not necessarily have an external expression, but, on the contrary, the restorative value of the act performed on the basis of this quality, mental state consists in the stimulation of some internalized behaviors (B.F. Skinner). The principle of the value centering of the artistic action (on activities / action, useful / useful, artistic image, creativity), constitutes the attitudinal-conceptual basis of the pupil for the spiritual-artistic acquisitions and the practical achievements; it involves the re-dimensioning of personal, attitudinal, behavioral factors, responsible for enriching the intimate universe, for cultivating a pedagogy of the self.

Psychology attests that it is through the person's property to propagate from the inside to the outside that the goals are revealed, for the achievement of which the actor of the process makes every effort in his activity, for which he prescribes the inner tendencies meant to conquer the peaks valuable situations in the fields of 
high spirituality and creativity. In the context of macrosystemic processes, the personalist orientation could be qualified as a win-win paradigm (S. Covey), which reflects the profit obtained by the student from society and which indicates what he himself offers to others. Such a paradigm of student orientation is an ideal model of education. In reality, however, there are frequent cases contrary to the one described above, namely, when the person seeks to obtain as much profit as possible from social institutions and, at the same time, to consume as little as possible own sources, which, in the end, are chosen with the paradigm of gain failure.

The principle of artistic introduction requires the establishment of an efficient correlation of individual and artistic environments through the deliberate reception / comprehension / interpretation by adolescents of the artistic message and the aesthetic essence of the work of art, as well as through the design of personal maps. The person's introduction to artistic content is certified by his deeply specific behavior, expressed by the notion of ,intentional attitude of action". This principle increases the efficiency of the process of theoretical and practical knowledge of art on the grounds that the two constituent parts of the principle focus the potential and energies of the student both through the internalization and externalization of artistic materials. The power of the nominated principle increases in proportion to the increase in the connection intensity, and this amplifies the processes of artistic introduction of the student, who testify about the level of his specific performance. The principle of introduction affects in a positive way not only the education agents (teacher / pupil / student), but also the dimension of opening the curriculum to art disciplines.

The principle of creation and creativity is the edifying condition of the creation of beauty and good and the self-creation of the student's self, the elaboration of the personal ideal, "Conquering" one's own intimate universe. Artistic creation and creativity are to be directed so that the word / intonation and everything related to these communicative factors, have a permanent purpose to change their paradigm with the tendency to advance from the notion, meaning to artistic experience. The attention and effort of the student must be permanently oriented towards the individual particularities, constituents of the object of art / painting, music, choreography / with the artistic complement, because the last one constitutes what we usually to call by the notions: typical, characteristic, original.

The principle of artistic success prescribes a general and universal character to the cause and results of education. The engagement in the educational process of the success situations, conceived and instrumented through the methodological prism of the previously exposed principles, could contribute, in the most direct way, to the progressive and efficiency of the adolescent's action, only if and provided that success will be examined both as a condition and as a purpose of artistic education, which implies the aspect of finality, the latter being supported by expectations, goals, projects - all forcing us to realize the plans drawn consciously and intelligently.

The praxeological principles as well as the laws of existence and activation, according to us, are not amorphous, unchanging postulates, but inherent images of 
changing events / facts / things, constantly available for reformation, restoration. The test stone in addressing the nominated principles is that the effectiveness of the functioning of each principle is examined from the positions of connecting the theoretical positions / approaches with its practical effects.

\section{Results}

The results of our research are emergently oriented to the efficiency of external factors of the educational process and factors related to human resources, in particular, the effectiveness of the musical-artistic action of the pupil / student and the dynamics of professional competence of the teacher. The two components of the educational process can relate effectively due to the functioning of the system of the principle of proactive personality education, therefore, we sought to develop answers to the question What takes place and less to the question How it takes place, in which process the action musical-artistic of the pupil / student and the dynamics of the professional competence of the teacher, realized according to the principle of proactivity and other four principles, exposed above, can be the object of the integration of the theoretical approaches and the practical implementations. In order to validate the theoretical assumptions presented, we performed the implementation experiment, according to several directions.

The first direction puts into practice the level of proactivity of the student / student at the stages of design, organization and realization of artistic action in relation to the interventions of the instructive-educational environment, expressed by indications of the teacher, authors of the textbook and other managerialpraxeological dispositions. The students of the experimental classes are trained in the exercise of accomplishing a series of items in various types of artistic actions, through which to demonstrate the level of independence and initiative by manifesting the skills of advancing the goal and designing their own steps of artistic actions by:

- description of the action route (at design level);

- highlighting the main and secondary action steps;

- predictability of possible errors and determination of measures to exclude them from the process;

- designating the nature and character of the possible operations to be performed;

- expecting strangers;

- highlighting the previously acquired experiential landmarks;

- determining the type and content of the action at the initial stage and anticipating possible interventions along the way;

- documentation of internal and external resources engaged in the process.

The second direction of the pedagogical experiment is related to the study of the abilities of the pupils / students to register behavioral-artistic formative value paradigms of receiver $\rightarrow$ appreciator. Based on the experimental conception, it is important to make value transfers: from the state of dependence $\rightarrow$ to the state of independence $\rightarrow$ and then to the state of intra independence, which means tending to change the behavioral paradigm, which it is directly linked to the power to dominate external artistic influences and to use internal acquisitions effectively. 
The third direction of the experimental study is dedicated to verifying the effects of opening the pupil / student to the spirit, to the intimate through the artistic. The change of the paradigm is valued: receiver (reader, listener, observer) $\rightarrow$ performer-artist.

The fourth direction, in this order of ideas, is dedicated to documenting the degree of efficient connection between the environments: instructiveeducational $\leftrightarrow$ individual $\leftrightarrow$ artistic, which relates to the respective relations: teacher $\leftrightarrow$ pupil / student; pupil / student $\leftrightarrow$ artistic contents. The designated formulas, obviously, lead us to the situations-relations: theoretical approaches $\leftrightarrow$ practical achievements; creative action $\leftrightarrow$ training / change.

The fifth direction of the pedagogical experiment is reduced to the demonstration of the role of personal and public success in the efficiency of artistic action of student as a fundamental praxeological factor in the promotion of a qualitative education and training. As a fundamental and integrative praxeological object of the experimental program must serve the artistic action of the student / student and the didactic action of the teacher with all forms, genres, constituent elements, nature and specific to their operation. In the program of the experimental study it is necessary to take into account the following personality qualities:

- attitudinal orientations, which in essence constitute a state of retreat / selforientation;

- autonomous, complete will, with full feelings;

- organizational culture;

- the level of manifestation of independence and initiative;

- the sense of value;

- successful situation.

In order to carry out a good instructive-educational practice in all fields, but especially in those referring to the specificity of manifesting through art, we found it opportune to develop a set of praxeological models, which would contribute to the conceptual re-orientation of practitioner. The models in question are focused on the main laws of efficient functioning of the components of artistic action. Each model includes the methodologies of a good development, reveals the possible positive or negative exponents of the targeted model, also each model highlights the finalities that the actors of the instructive-educational process can expect.

Relationship model: action - qualitative change. Positive opportunities of the model. Arguments. The student, being initiated in artistic actions, meditates, experiences deep or less deep feelings, but they are hidden from the sight of others. The person is the only observer and appreciator of inner phenomena. He and he alone accepts or rejects, overestimates or underestimates the „behaviors” received from works of art and which could take place, but which, for the time being, persist in a state of expectation, in a form tacit. The formativedevelopmental influence on the actor of the process does not differ in any way, according to the resources employed in the process, from other forms of behavior. 
- the student, especially in the artistic and creative fields, needs a self-closure (refuge inside) to check all the pros and cons of the stimuli coming from outside and inside;

- being a self-observer, the student has access to everything that happens in the internal spaces, which are, in many respects, closed to an external observer;

- the model of idealized behavior is a method specific to the field of artistic creation, which prepares the student for the identification of values and anticipation of musical-artistic events, without him performing external actions;

- the capitalization of the model, in balanced areas, leads (should lead!) To the musical-artistic independence and intra independence of the student;

- the model of the idealized behavior, formed / constructed inside the person, does not disappear without traces, but on the contrary, it is rigorously applied in the subsequent behaviors, manufactured by external actions;

- students who master the manifest abilities of the targeted model, as a rule, show high performances in the field of musical-artistic creation.

Negative opportunities of the model:

- students' abilities are left without a field of manifestation or camouflaged and not directly observed by the teacher, colleagues, parents;

- the idealized musical-artistic behaviors are directed and evaluated with great difficulties by external factors;

- the impossibility of involving the teacher in the tacit behavioral processes makes this model to be left to fate or completely to be excluded from the educational environment.

- students willing to apply in practice the model of idealized behavior without any situational transfer suffer defeats, are not accepted by the circumstance.

For the musical action, the targeted behavior is an immeasurable importance, because it allows the student to develop the ability to choose, to take responsibility for the performances.

\section{Conclusions}

The problem of relating educational theory and practice is a key issue in pedagogy. The desideratum of balancing the actions of the educational-theoretical environment and the educational-practical environment is not to frustrate / trigger the traditional actions, but to re-orient them towards qualitative change and progress. At the moment, the institutionalized educational system does not have the sources provided especially for the enrollment in practice of the theoretical approaches, except by way of improving the teachers for the specialized courses.

That is why today's researcher is obliged not only to elaborate consistent researches, but also to invest their results in the educational-practical environment. Factors of positive influence of the relationship: theory - practice:

- the level of pedagogical experience;

- specialization (teacher of music and choreography, teacher of music and primary classes, teacher of primary classes, teacher of music and choir, teacher of music and musical instrument, etc.);

- related to the level of studies (arts / music school, high school, faculty); 
- creative spirit (demonstrated or possible performances, inferior, average, superior endowment, motivated, oriented activation, "multiple intelligence" (Gardner, 1983).

- individual variable;

- social variables.

\section{References}

1. BABII, Vladimir, Eficienţa educaţiei muzical-artistice, Chişinău, Editura „Elena V.I.”, 2005

2. BABII, Vladimir, Teoria şi praxiologia educaţiei muzical-artistice, Chişinău, Editura "Elena V.I.", 2010

3. BABII, Vladimir., BULARGA, T. Succesul artistic al elevilor din perspectiva devenirii personalității social activel Materialele Conferinţei ştiinţifice naţionale cu participare internaţională "Fundamente psihopedagogice ale prevenirii şi combaterii violenţei în sistemul educaţional", 10 octombrie 2014, Univ. Ped. de Stat "Ion Creangă", Fac. Psihologie şi Psihopedagogie Specială, Catedra Psihologie, Chişinău, 2014, p. 214-224. ISBN 978-9975-115-53-7. 37.015.3(082) $=135.1=161.1 \mathrm{~F} 97$

4. BABII, Vladimir. Praxiologia educaţiei artisticel Educaţia artistică în contextul mediului social-cultural al sec. al XXI-lea, Bălți, 2014, p. 17-20. ISBN 978-99-75-4227-3-4

5. BABII, Vladimir., Vasile, V. Aptitudinile muzicale între realitate şi ideal/ Educaţia artistică în contextul mediului social-cultural al sec. al XXI-lea, Bălți, 2014, p. 13-17. ISBN 978-99-75-4227-3-4

6. BABII, Vladimir. Dinamica gîndirii muzicale / În: Materialele Conferinței științifice internaționale «Ion Gagim şi universul muzicii». Academia de Științe a Moldovei. Editura Artes, Iaşi., p. 179-183. ISBN 978-606-547-192-4

7. BABII, Vladimir., BULARGA, Tatiana. Dimensiunea educațională a creativității muzicale in cadrul euroregiunii Siret-Prut-Nistru/ Editia a-X-a "Dezvoltarea economico-sociala durabila a euroregiunilor si a zonelor transfrontaliere în cadrul forumului transfrontalier al euroregiunii Siret-PrutNistru", Bălţi, p. 21-22. ISBN 978-606-687-109-9

8. BULARGA, Tatiana, BABII, Vladimir. The success of artistic education: integration approache. In: Review of Artistic Education. Artes Publishing House, Iași. ISSN=2069-7554 ISSN-L=2069-7554. Included in CEEOL, EBSCO, Index Copernicus, 2014, p. 250-259 